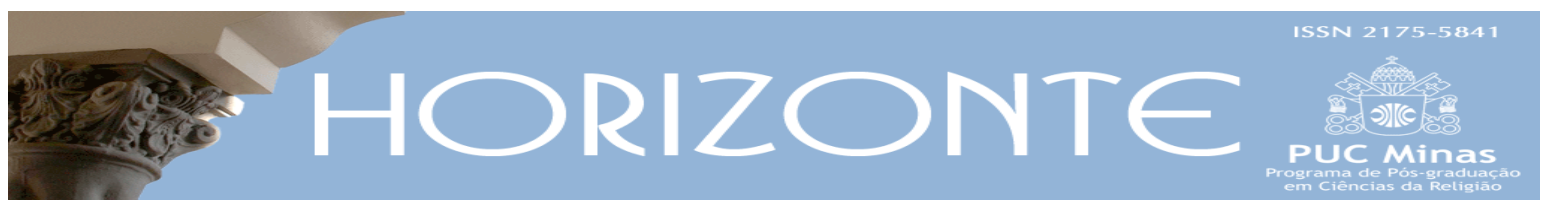

Temática Livre - Artigo original

(ब) $\odot$

DOI - 10.5752/P.2175-5841.2020v18n55p378

\title{
Prédicas em torno da conquista e manutenção de Ceuta
}

\author{
Discourses about the conquest and retaining of Ceuta
}

\author{
Leandro Alves Teodoro*
}

\begin{abstract}
Resumo
O segundo cronista e guarda-mor da Torre do Tombo - Gomes Eanes de Zurara notabilizou-se pela produção de crônicas acerca da conquista e manutenção da praça de Ceuta no século XV. Com a finalidade de explorar as impressões desse cronista, o presente trabalho abordará como Zurara fez um uso edificante de duas de suas fontes: o discurso do conde D. Pedro de Meneses e um reportatio do sermão do fr. João Xira. Mais precisamente, o alvo deste estudo é examinar em que medida Zurara reproduziu as palavras dessas célebres figuras na expectativa de legitimar a incursão militar da Coroa no norte da África. Com ênfase na descrição do referido oficial da Torre do Tombo, o alvo consistirá em analisar a função da prédica de um religioso e de um cavaleiro para a exortação dos portugueses enviados a essa região em um período de fortalecimento das bases políticas e religiosas de Portugal.
\end{abstract}

Palavras-chave: Gomes Eanes de Zurara. Crônicas portuguesas. Formação moral. Século XV.

\begin{abstract}
The second chief-chronicler and chief-keeper of the Torre do Tombo (National Archives), Gomes Eanes de Zurara, was renowned for writing chronicles full of particulars about the conquest and retaining of Ceuta in the fifteenth century. Seeking to explore the impressions of the royal chronicler, the present work will discuss how Zurara made use of two of his sources: a speech by count D. Pedro de Meneses and, especially, one reportatio by Fr. João Xira. More precisely, the aim of this study is to examine to what extent Zurara reproduced the words of these famous figures expecting not only to legitimize the royal military incursion into North Africa, but also to instruct the Portuguese knights and counsel them on their role in society. Without dwelling too much on the character of Zurara, the intent is to analyse the role of the discourse of a clergyman and that of a knight in exhorting the Portuguese soldiers sent to that region, during a period of strengthening of the political and religious bases of Portugal.
\end{abstract}

Keywords: Gomes Eanes de Zurara. Portuguese chronicles. Moral formation. Fifteenth century.

Artigo submetido em 11 de outubro de 2019 e aprovado em 12 de abril de 2020.

Pesquisa realizada mediante Auxílio à Pesquisa Jovem Pesquisador - FAPESP.

* Doutor em História pela Unesp. Professor da Unicamp e da Unesp. País de origem: Brasil. E-mail: lleandroateodoro@gmail.com 


\section{Introdução}

Escrita entre 1449 e 1450, a Crónica da Tomada de Ceuta, do cronista-mor e guarda-mor da Torre do Tombo - Gomes Eanes de Zurara - notabiliza-se por reportar a conquista portuguesa dessa célebre cidade. Em certa altura da crônica, ao descrever as motivações religiosas que teriam estimulado os portugueses a expandir o território cristão, o cronista reproduz este trecho da prédica proferida pelo fr. João Xira, confessor de D. João I, aos cavaleiros antes de partirem para o norte da África:

Amigos, deveis de ter que a vida destes infiéis não é ${ }^{1}$ entre nós por virtude da sua própria força, somente por vontade do Senhor Deus, ao Qual praz dar lugar que nos deem fadiga e trabalho, porque nós, afligidos e trabalhados pelo poder de tão vis inimigos, conheçamos os muitos erros que contra Ele cometemos, e nos tornemos a Ele por verdadeira penitência. E nós, assim tornados ao verdadeiro caminho, possamos d'Ele receber esforço e ajuda para os destruir. (ZURARA, 1915, p. 161).

Depois de anunciar essas palavras - tomando como base um reportatio, isto é, uma cópia do sermão realizada provavelmente por um dos ouvintes - o mesmo religioso se refere ao objetivo evangelizador da missão empreendida pelos portugueses e destaca os méritos desses homens por cumprirem a tarefa a eles imbuída. Ao reproduzir o discurso de fr. João Xira, o cronista caracteriza a conquista de Ceuta como uma guerra santa: uma incursão militar voltada para a promoção da fé em terras ocupadas por povos de outros credos. $^{2}$

Antes mesmo da escrita da Crónica da Tomada de Ceuta - por volta de 1458 - o cronista Gomes Eanes de Zurara começou a elaborar a Crónica do Conde D. Pedro de Meneses para narrar os eventos que se seguiram à conquista da praça de Ceuta. (SERRÃO, 1972, p. 65-84; CARVALHO, 1949).3 Esse letrado cita um discurso realizado pelo nobre D. Pedro de Meneses, escolhido como governador dessa cidade, com o objetivo de encorajar os cavaleiros enviados ao norte da África.

\footnotetext{
${ }^{1}$ Emprega-se o verbo "ser", neste caso, no sentido de "existir".

2 A noção de guerra santa, aqui, está atrelada à noção de guerra justa, ou seja, dentre o rol de justificativas possíveis para iniciar uma guerra no final da Idade Média figurava também como justo guerrear em nome da expansão da fé católica (Cf. CONTAMINE, 2002).

3 A respeito da produção de Zurara, ver Carvalho (1949).
} 
Segundo Zurara, o conde teria dito estas palavras para animar seus subordinados antes de chegarem à cidade de Ceuta: "hei grande desprazer vendo assim vossos rostos molhados e vossas caras tristes, como gente temerosa e desesperada em que não há virtudes nem fortaleza [...]”. (ZURARA, 1997, p. 216). Apregoando palavras que deviam incutir a confiança necessária aos portugueses instalados na linha de frente da guerra contra os infiéis, D. Pedro de Meneses buscou estimular os homens a serem guerreiros comprometidos com a defesa do reino; consequentemente, das suas crenças.

Partindo das impressões de Gomes Eanes de Zurara acerca do sermão do fr. João Xira e do discurso do conde D. Pedro de Meneses, o foco deste trabalho será a memória registrada pelo cronista acerca da exortação moral dos nobres portugueses enviados a Ceuta para serem guardiões da fé cristã num território hostil. Longe - contudo - de questionar se a pregação do franciscano João Xira ou mesmo a exortação do conde D. Pedro de Meneses teriam sido uma mera criação desse cronista, o presente ensaio interrogará em que medida a produção cronística de Gomes Eanes de Zurara procurou preservar exemplos de conduta que inspirassem os cavaleiros a abrandar seus sentimentos e preparar a alma e o corpo para a guerra santa.

\section{Os testemunhos relatados por Gomes Eanes de Zurara}

No início da Crónica da Tomada de Ceuta, visando definir melhor as linhas condutoras de seu labor cronístico, Gomes Eanes de Zurara afirma que havia escrito acerca daquele assunto para "esguardar quatro coisas; a saber, grande amor da Fé, grandeza de coração, maravilhosa ordenança, e proveitosa vitória”. (ZURARA, 1915, p. 8). Ao relatar o que se julgava serem as verdades relativas aos fatos da conquista e manutenção da cidade de Ceuta, ele segue o mesmo compromisso assumido por seu predecessor, o guarda-mor da Torre do Tombo e cronista-mor do reino Fernão Lopes, de descrever uma história fiel aos testemunhos colhidos e aos documentos levantados para a elaboração da narrativa. (FRANÇA, 2006, p. 123-125). Desse modo, a citação do discurso do fr. João Xira ou 
do conde D. Pedro de Meneses consistia em um recurso utilizado para certificar o leitor de que as informações transmitidas eram verdadeiras; por consequência, confiáveis. Citando testemunhos de um religioso, Zurara visava construir uma história do reino e da casa de Avis em que um dos capítulos mais importantes dizia respeito à expansão da fé: ao serviço prestado pelos cavaleiros portugueses para proteger, não apenas o território português, mas também a doutrina cristã. $\mathrm{Na}$ visão do cronista e de suas testemunhas, a defesa da casa de Avis e a propagação do cristianismo eram - aliás - dois alvos indissociáveis.

\section{Figura 1 - Crónica da Tomada de Ceuta, por Gomes Eanes de Zurara}

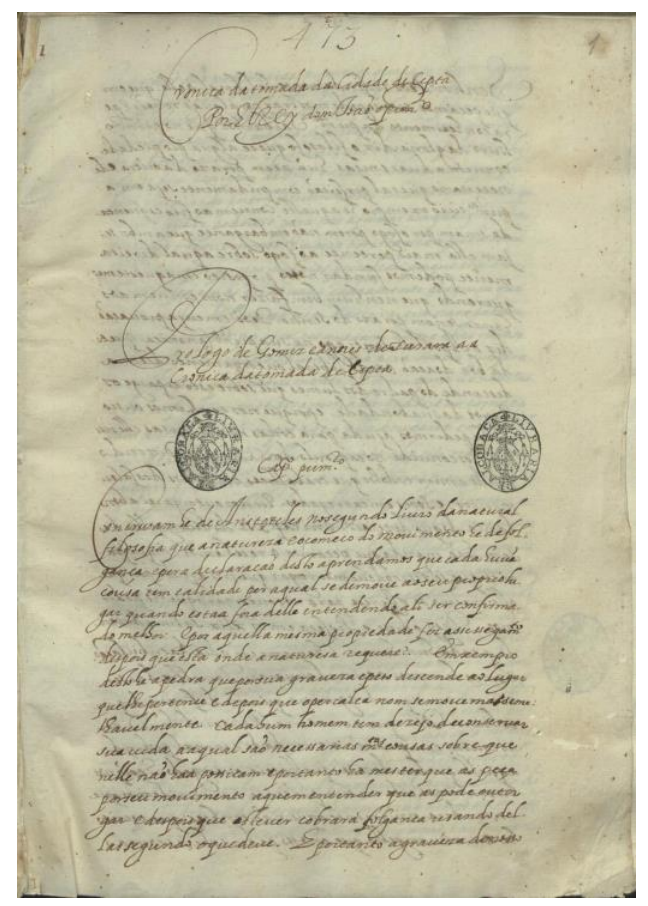

Fonte: ZURARA, Gomes Eanes de. Crônica da Tomada de Ceuta, [1601-17oo] Biblioteca Nacional de Portugal. Cota do exemplar digitalizado: alc-317.

Tal relação entre a guerra e a defesa da religião é um tema recorrente em toda a produção de Gomes Eanes de Zurara, e ganha um peso expressivo no capítulo de número 10 da Crónica da Tomada de Ceuta. Nessa altura da obra, o cronista explica como o rei D. João I procurou garantir que a investida militar por parte dos portugueses em Ceuta era legítima e meritória aos olhos de Deus. Por isso, convocou vários letrados do reino a aconselhá-lo - entre os quais o mestre fr. 
João Xira e o doutor fr. Vasco Pereira - que eram os seus confessores, e o Infante D. Duarte. Segundo o mesmo cronista, os letrados consultados responderam que a própria história respaldava a conquista de Ceuta, pois outros governantes, como o rei D. Fernando de Leão, já haviam dado provas da superioridade da fé cristã e da necessidade de conter a presença mourisca (ZURARA, 1915, p. 31). Dito de outro modo, o sucesso de homens que no passado foram exemplo de conduta e de vitória legitimariam, aos olhos dos letrados, o plano esboçado por D. João I de investir militarmente no norte da África.

A necessidade de justificar a guerra santa fez com que Gomes Eanes de Zurara respaldasse seu discurso inclusive na reprodução dos sermões proferidos pelo fr. João Xira aos nobres enviados para combater os mouros. No final da Crónica da Tomada de Ceuta, altura em que esse cronista descreve o contexto em que os filhos de D. João I são armados cavaleiros, é contado que o fr. João Xira teria realizado "uma pregação com muitas autoridades da Santa Escritura, aprovando o grande serviço" que Deus recebera com aquele feito. (ZURARA, 1915, p. 254). O cronista menciona essas palavras com o objetivo de escrever uma memória dos fatos a partir de diferentes ângulos, perpetuando desde o conflito entre cristãos e mouros até os sermões que teriam inspirado os portugueses a abrandar a tristeza de deixar seus familiares para enfrentar um inimigo da Cristandade. Essa meta de narrar a própria exortação dos cavaleiros foi atendida por meio da elaboração de trechos como este em que o cronista reporta a homilia do fr. João Xira: "vós tendes feito o verdadeiro templo e verdadeira casa a Nosso Senhor, na qual coisa O servistes em duas guisas”. Explica ainda que, enquanto a primeira guisa era o mérito de conseguir expulsar os infiéis da cidade de Ceuta e tirar de suas mãos a posse de suas mesquitas, a segunda consistia em tornar aquele lugar um abrigo para os cristãos. (ZURARA, 1915, p. 255). Ao citar esse sermão, o alvo de Zurara era imortalizar as façanhas desse franciscano que agiu junto aos nobres portugueses a fim de convencê-los da grandiosidade da missão a eles investida. 
Além das palavras do fr. João Xira, Gomes Eanes de Zurara também reproduziu - entre outros testemunhos, como adiantado acima - as prédicas do conde D. Pedro de Meneses, que evidenciam os valores exortados na praça de Ceuta para estimular práticas varonis e convencer os nobres a abrandar o medo da morte e se dedicarem à guerra santa. Enquanto fr. João Xira possuía a autoridade de seu discurso atestada por ser confessor do rei e um aclamado pregador franciscano, o conde D. Pedro ganha destaque, ainda maior que esse religioso, não apenas por se consagrar cavaleiro e protagonizar uma das crônicas de Zurara, mas também em razão de seu potencial como orador e conhecedor dos princípios morais daquela sociedade. As qualidades desse conde como testemunha fiável são atestadas em diferentes momentos da crônica, sobretudo no capítulo $\mathrm{X}$ da Crónica do Conde D. Pedro de Meneses em que se lê: "era o conde D. Pedro de graciosas palavras e homem que falava sabedoramente, como aquele que em sua mocidade aprendera muito \{das\} artes liberais, e assim tomarão aquelas gentes temerosas ousadia daquelas razões [...]”. (ZURARA, 1997, p. 219-220).

Figura 2 - Prédicas do conde Dom Pedro de Meneses, por Gomes Eanes de Zurara

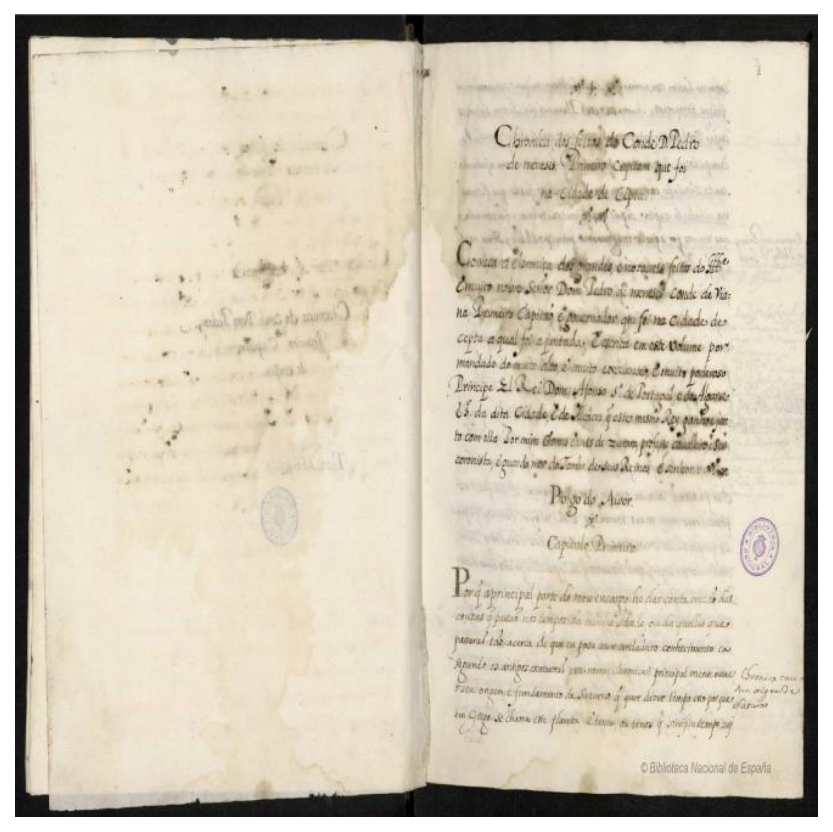

Fonte: ZURARA, Gomes Eanes de. Crónica dos feitos do conde Dom Pedro de Meneses, primeiro capitão que foi na cidade de Ceuta por mim, Gomes Eanes de Zurara, [1601-1700]. Biblioteca Nacional de Portugal. Cota do exemplar digitalizado: cod-12982. 
Embora o discurso do Conde D. Pedro de Meses ocupe um espaço estratégico na trama de Gomes Eanes de Zurara, ele não é único na trama do cronista. Na mesma Crónica do Conde D. Pedro de Meneses, Zurara menciona uma prédica do rei D. João I: "Servidores e amigos, eu vos escolhi entre tantos e tão leais vassalos como vedes que aqui de presente tenho para me servir de vós na guarda desta cidade, e, quanto isto seja de minha honra e serviço vos, o podeis bem conhecer, e por isto seria escusado de fazer-vos sobre sua guarda mais longo sermão". (ZURARA, 1997, p. 205). A partir dessas palavras, Zurara menciona uma longa prédica em que tal monarca incita seus vassalos a guerrear contra um inimigo da fé cristã em prol de suas honras. (ZURARA, 1997, p. 204). As palavras de D. João I foram mencionadas em primeira pessoa, de modo que o personagem dava sua voz à narrativa, para gerar o mesmo efeito retórico das citações dos sermões de fr. João Xira e da prédica do conde D. Pedro de Meneses; a saber: conferir maior precisão e riqueza documental à narrativa sobre a conquista e manutenção da praça de Ceuta. Além disso, esse cronista também visava conservar as palavras de grandes testemunhas para que homens de outras gerações pudessem conhecê-las e apreciá-las - testemunhas tanto do campo religioso quanto da linha de frente da guerra, de reis e de seus mais leais cavaleiros. As crônicas de Gomes Eanes de Zurara não foram elaboradas para cumprirem a função de uma recolha de exempla; de uma compilação de historietas moralizantes que poderiam ser lidas, compiladas, reproduzidas e - consequentemente - disseminadas pelas bocas de religiosos e clérigos em suas pregações. Por seu valor testemunhal da história, as crônicas em que as palavras de D. Pedro de Meneses e do fr. João Xira foram citadas serviam para um fim menos prático ou imediato que as recolhas de exempla ou de sermões: salvar a memória do esquecimento.4 Zurara escreveu - desse modo - um conjunto de obras para que fossem guardadas em um arquivo, tal como faziam com boa parte dos documentos jurídicos confeccionados pela chancelara régia.

\footnotetext{
${ }^{4}$ Para um panorama da relação entre escrita da história, conservação da memória e fortalecimento dos poderes monárquicos, ver Guenée (1980).
} 
Vale ressaltar, contudo, que - apesar de crônicas como essas de Gomes Eanes de Zurara não tivessem como meta ensinar pregadores a preparar o seu próprio discurso, como visavam os sermonários ou recolhas de exempla - são documentos que permitem entrever ricas impressões a respeito da maneira como uma prédica pública era ministrada no século XV. Por exemplo, no caso do discurso do franciscano fr. João Xira, são detalhados elementos concernentes ao público de seu sermão e aos objetivos moralizantes desse conhecido pregador português - como já foi assinalado acima. Segundo Zurara, quando os cavaleiros estavam reunidos em Lagos, sul de Portugal, foi imbuída ao frei João Xira a tarefa de explicar a eles o motivo de estarem ali e o plano da missão a ser realizada em África, pois até então o projeto da tomada de Ceuta era mantido pelo rei D. João I como um segredo. Proferido no dia 28 de junho de 1415, esse discurso se notabilizou por conter as palavras que revelaram a verdade aos portugueses acerca de seus destinos como cruzados em terras de infiéis. Essa prédica do frei João Xira em Lagos é um dos grandes eventos da cronística de Zurara justamente por delimitar o momento em que os portugueses, segundo esse letrado, tomaram consciência de que participariam de uma nova cruzada.

O discurso do conde D. Pedro de Meneses, e o sermão do fr. João Xira especialmente -apelam para o papel edificante da guerra em Ceuta com a finalidade de ensinar aos cavaleiros portugueses que combater os mouros era um ato de fé. Gomes Eanes de Zurara destaca um trecho da prédica do fr. João Xira que resume magistralmente as lições destinadas aos homens, que deviam colocar o seu corpo à disposição da coroa portuguesa a fim de ajudar na conservação e propagação dos costumes cristãos. Segundo o cronista-mor do reino, esse religioso acentuou, a partir de uma paráfrase da Epístola aos Romanos do apóstolo São Paulo, que "não somente aqueles que são contra a fé são dignos de morte, mas ainda os que o consentem não lho contrariando com todas suas forças." Por isso, não se podia deixar de destacar que "aquele que se tem por católico e verdadeiro cristão, e com toda sua força não se dispõe a defender a sua santa fé, não é verdadeiro cavaleiro, nem membro de Jesus Cristo, nem tem parte alguma com Ele [...]”. (ZURARA, 1915, p. 157). As impressões do cronista Gomes Eanes de Zurara 
dão pistas que nos permitem penetrar no território da construção dos valores apregoados na corte dos reis e de uma memória edificada para inspirar as ações de futuros governantes.

Vejamos melhor agora a proposta das prédicas do fr. João Xira e do conde Pedro de Meneses tomadas por Zurara mencionadas acima, bem como a relação entre elas e o conteúdo de outras obras do período que ajudaram a erigir os andaimes morais da corte de Avis.

\section{0 controle dos sentimentos dos cavaleiros de Ceuta}

Para enfatizar as práticas devocionais ensinadas aos cavaleiros pelo fr. João Xira, o cronista Gomes Eanes de Zurara menciona esta parte da prédica do franciscano:

Usando de meu ofício vos requeiro e rogo a todos quantos aqui presentes sois, que considereis bem, em vossas consciências, quaisquer pecados, males ou erros, que tenhais cometidos, e que peçais ao Senhor Deus perdão deles com todo coração e vontade, e façais deles penitência, havendo firme propósito de vos guardar de pecar daqui em diante. (ZURARA, 1915, p. 161).

O cronista ressalta que os homens que partiram para a conquista da praça de Ceuta tinham de corrigir suas consciências e considerar a guerra como obra pia, pela qual não apenas ajudariam a disseminar a fé cristã, mas também provariam seu amor a Deus. Ecoando lições importantes de manuais de confessores e de partes das sumas teológicas que tinham como alvo as formas de correção dos pecados mortais, o sermão do fr. João Xira se estrutura em torno de uma trama em uma dessas lições enfatizava o potencial salutar da penitência para a correção das falhas cometidas. Nessa trama de sermões transcritos nas crônicas, ganha relevo portanto - uma temática de suma importância para os jogos moralizantes desses tempos: os gestos e a própria maneira como os cavaleiros exteriorizavam os sentimentos.

Gomes Eanes de Zurara, na citada Crónica do Conde D. Pedro de Meneses, condena - como visto no início deste trabalho - os cavaleiros que choravam por 
medo da ameaça mourisca. Ao citar o discurso do conde D. Pedro, assevera o cronista que ele teria perguntado o motivo de estarem com "os corações molharigos e afeminados". (ZURARA, 1997, p. 218). Esses dois adjetivos empregados para caracterizar os corações dos cavaleiros serviam, desse modo, para taxar esses homens de fracos e inconstantes; foram utilizados para desqualificar o comportamento de nobres não considerados espiritualmente fortes o suficiente para frear os impulsos e controlar o medo. Acerca desse jogo vocabular, a obra Vita Christi de Ludolfo da Saxónia - impressa em Portual no ano de 1495 pelas mãos dos impressores Valentim Fernandes da Morávia e Nicolau da Saxónia - considera que o vício faz os "corações molharigos e moles," de forma que o mal regimento "pode muito corromper a força". Por isso, o autor afirma, parafraseando o filósofo estóico Sêneca, que se deve "vencer e impugnar os deleites logo no começo". (SAXÓNIA, 2013, p. 103).

O livro Horto do Esposo - composto no mosteiro de Santa Maria de Alcobaça, entre os séculos XIV e XV - possui um inventário de máximas sobre a virtude da fortaleza que nos permite explorar melhor o papel edificante da prédica do conde D. Pedro reproduzida por Zurara. Diz a obra de cunho ascético que muitos homens se "prezam muito na fortaleza corporal que é contada como uma bem-aventurança entre os bens naturais do corpo.” Explica esse tratado que "esta fortaleza é mais danosa que proveitosa. Por isso, diz São Bernardo: Sempre no corpo robusto e forte jaz coração mole e descontrolado, e no corpo fraco e enfermo mais forte e mais prestes é o espírito". (FREIRE; GODINHO, 2007, p. 162). Conclui, depois de finalizar uma paráfrase de São Jerônimo - um dos Padres latinos da Igreja dos séculos V e VI - ao dizer que a "fortaleza do corpo é fraqueza da alma”. (FREIRE; GODINHO, 2007, p. 163). Embora o Horto do Esposo fosse um livro repleto de historietas acerca do valor positivo da vida reclusa, as suas ponderações ecoavam por outras obras que também consideravam a fortaleza como o fortalecimento do espírito. A produção da corte dos reis de Avis alimentava-se dessas referências monásticas e ajudava a disseminar pelo reino conselhos e admoestações que religiosos como os monges brancos vinham elaborando em Alcobaça desde o final do século XIV. (Cf. MONGELLI, 2001, p. 53-55). 
Mesmo que o alvo principal de Gomes Eanes de Zurara não seja, como o do Horto do Esposo, a formação cristã por meio de prescrições relativas aos costumes cotidianos, a sua Crónica do Conde D. Pedro de Meneses também reafirma o pressuposto cristão de que a força física não garantia a fortaleza do espírito nem a grandeza dos feitos. Zurara adita que este nobre ainda teria apregoado que "não são as forças dos corpos, mas as fortalezas dos corações que acabam os feitos das batalhas". (ZURARA, 1997, p. 216). Visando confortar os cavaleiros portugueses enviados ao norte da África, o mesmo cronista - na Crónica da Tomada de Ceuta cita uma prédica do papa Leão, o Grande, em que este aconselha o fiel a tirar "todo pavor e espanto, e" pensar em lutar "esforçadamente contra os inimigos da santa fé". O mesmo trecho do discurso do papa, parafraseado pelo cronista, assevera igualmente que a morte se torna profícua ao espírito quando resulta de um ato de defesa da fé cristã. (ZURARA, 1915, p. 182). Em ambas as crônicas, Zurara procura construir um modelo de cavaleiro devoto, lançando mão de exemplos de homens que no passado recente e remoto souberam ser modelos de cristãos protetores da sua religião.

No que concerne à formação dos nobres, inclusive daqueles que participaram da conquista de Ceuta, uma das obras mais celebradas na corte de Avis para o estabelecimento de parâmetros de ação para esses homens era o Leal Conselheiro, do monarca D. Duarte. Descrevendo os riscos dos pecados mortais e as consequências positivas da prática da penitência, o referido rei penetra no território das obras pastorais dessa época. D. Duarte afirma que S. João Batista, mensageiro de Cristo, havia dito: "pelas lágrimas percalça o homem relevamento dos pecados [...], por isso lavarei em cada uma das noites o meu leito e regarei o meu estrado com as minhas lágrimas”. Segundo D. Duarte, o mesmo S. João Batista também teria recomendado: "demostrando que as não tomou em vão (as lágrimas), arredai-vos de mim os que obrais maldades, pois o Senhor ouviu a voz de meu choro". (DUARTE, 1998, p. 162). Na visão do monarca avisino, o choro de S. João Batista devia ser tomado como inspiração pelos membros da Corte, a fim de reavaliarem suas práticas e se tornarem fiéis mais comprometidos com os deveres de seu estado. No que se refere à penitência, o irmão de D. Duarte, o Duque de 
Coimbra e o confessor deste nobre - o fr. João Verba - anunciaram no livro da Virtuosa Benfeitoria, outra grande referência da Ínclita Geração, que a penitência e o choro serviam como forma de petição (PEDRO, 1981, p. 674), um meio de usar o próprio corpo para suplicar perdão pelos pecados mortais.

$\mathrm{Na}$ trama construída por Gomes Eanes de Zurara, enquanto o choro decorrente da dor dos pecados era exaltado, as lágrimas derramadas por medo da guerra não deixavam de ser reprimidas e vistas como sinal de fraqueza. Visando convencer os cavaleiros a conter lágrimas de medo, o conde D. Pedro de Meneses teria citado os nomes de grandes guerreiros responsáveis por defender a fé cristã, homens não apenas de corpos fortes, mas especialmente de espíritos banhados pela devoção de suas práticas piedosas. Para revestir seu discurso com um exemplo marcante, conta Zurara que o nobre destacou o empenho, tanto de Afonso Henriques por iniciar as investidas contra os infiéis no século XII, quanto dos descendentes desse monarca que, entre outras proezas militares, conseguiram tomar "o reino do Algarve com a maior parte da Extremadura". Esses feitos e qualidades do primeiro monarca constituem exemplos dignos de memória, frisando D. Pedro de Meneses que "aquela antiga virtude devia estar sempre" na lembrança (ZURARA, 1997, p. 218). Contra os cavaleiros considerados pusilânimes, o conde lança exemplos de homens que tinham na virtude da fortaleza o esteio de suas ações bélicas, já que guerreavam contra os inimigos de suas crenças.

Ao se espelharem em ações de monarcas como Afonso Henriques precursor da guerra de Reconquista em Portugal -, os cavaleiros sob a tutela do conde D. Pedro de Meneses tinham não apenas de defender a praça de Ceuta, mas também de recuperar das mãos dos mouros toda a outra terra por eles injustamente possuída, pois dizia respeito a um território que pertencia aos cristãos por direito. Na visão desse nobre, não havia muros nem torres que impedissem o poder de Deus; por isso, todos precisavam guardar este conselho: "se nossa tenção for firmada em lhe fazer (a Deus) aquele serviço que Lhe por nós, como seus fiéis e verdadeiros cristãos, é devido, Ele estará conosco [...]” (ZURARA, 1997, p. 218219). 
Gomes Eanes de Zurara, ao procurar convencer os cavaleiros de seu tempo e das gerações vindouras a guardar a virtude da fortaleza, visava fazer dos fidalgos portugueses exemplos de guerreiros cristãos que não se furtavam da prática da penitência, da purgação de seus erros e da obrigação de serem constantes e equilibrados para combater os inimigos da fé cristã. A partir da reprodução do discurso do fr. João Xira e do conde D. Pedro de Meneses, o cronista sustenta que os cavaleiros tinham de lamentar por suas faltas, de forma que o corpo robusto não era a única qualidade esperada de um nobre a serviço da Coroa portuguesa e da Igreja. Como tinham de servir de modelo aos homens comuns e serem os guardiões do reino, os enviados a Ceuta precisavam assumir a responsabilidade de serem exímios combatentes e, ao mesmo tempo, zelosos por suas crenças e práticas de devoção.

As impressões de Gomes Eanes de Zurara são ricas referências acerca da maneira como os letrados quatrocentistas definiam os valores varonis de um cavaleiro, isto é, as práticas que os grandes homens do reino tinham de ostentar diante de outros membros de seu grupo. Esse cronista ressalta, como outros de seus congêneres, que um cavaleiro devia agir, mesmo no campo de batalha, movido por sua fé e pelos ensinamentos deixados por Cristo. Esse tipo de nobre cavaleiro era tão comum de ser exaltado que o cronista-mor Rui de Pina aponta como exemplo de cavaleiro que conseguia atender a essa expectativa o próprio D. Duarte, filho de D. João I. Reporta esse letrado que o rei Eloquente "foi príncipe muito católico e amigo de Deus," dando claras provas de sua devoção, pois sempre "recebia os sacramentos, ouvia os ofícios divinos e cumpria muito perfeitamente as obras da misericórdia; foi muito piedoso [...]" (PINA, 1977, p. 495). Acerca da construção desse tipo de modelo de conduta, Zurara, antes mesmo de Pina elaborar a Crónica de D. Duarte, pintou um retrato semelhante da figura de outro D. Duarte, o filho do supracitado D. Pedro de Meneses. Tal cronista salienta, na Crónica de D. Duarte de Meneses, que este nobre foi um "homem devoto e amigo de Deus e guardador de Sua lei” (ZURARA, 1978, p. 49). 
O público alvo das obras cultivadas na corte eram os nobres do séquito régio, descendentes dos varões que lutaram ao lado de D. João I entre 1383-1385 para impedir a incorporação de Portugal ao reino de Castela (VENTURA, 1992). Uma parte considerável dos homens que estavam ao lado do progenitor dos príncipes de Avis era formado por simples peões (MORENO, 2000, p. 53): pessoas de camadas inferiores a dos cavaleiros mais tradicionais e que - por isso - menosprezavam as regras da Corte, bem como os elementos basilares da fé cristã. Eram homens que precisavam ser iniciados nos fundamentos da moral cristã para que pudessem servir, da melhor maneira possível, ao rei: ao reino.

A primeira geração dos príncipes de Avis - a geração que estabilizou a política do reino e fincou raízes cristãs na África - tinha como uma de suas referências as recomendações das Siete Partidas a respeito da conduta a ser tomada pelo monarca ideal. Diz esse corpus jurídico, elaborado no reinado de Afonso X tido como fonte de inspiração não apenas nos reinos de Castela e Leão, mas também em Portugal - que "vigários de Deus são os reis cada um em seu reino, postos sobre as gentes para mantê-las em justiça e verdade quanto ao temporal, bem assim como o imperador em seu império" (LA REAL ACADEMIA DE LA HISTORIA, 1807, p. 24). Assumindo o papel de "vigário de Deus", D. Duarte se responsabilizou pela aplicação da justiça e pela saúde espiritual de seus súditos, a fim de manter a harmonia do reino. Desde os tempos de D. João I, em que confessores como fr. João Xira pregavam para as grandes figuras de Portugal, os monarcas mostravam-se preocupados com a formação moral dos homens que protegiam o reino. Especialmente no advento da dinastia de Avis, período em que confessores como fr. João Xira pregavam para as grandes figuras de Portugal, os monarcas portugueses se mostravam mais preocupados com a formação moral dos homens que protegiam o reino. 


\section{Considerações finais}

A trama dos sermões reproduzidos por Gomes Eanes de Zurara dá pistas portanto - de como os homens quatrocentistas buscavam exprimir seus sentimentos mais íntimos, como a fé e o medo. É no contexto da conquista e da manutenção de Ceuta que a Corte avisina investe mais ordenadamente na produção de obras destinadas, entre outros objetivos, a ensinar os cavaleiros a controlar seus anseios e a confessar a sua fé. Em poucas palavras, as obras do séquito régio foram o baluarte da aprendizagem de gestos e comportamentos tidos como fundamentais para serem praticados pelos grandes fidalgos do reino, que deviam se colocar como exemplo de conduta aos demais homens de Portugal.

Numa época em que o fazer cronístico se amparava no discurso direto dos personagens mencionados para fundamentar a informação reportada, o cronista Gomes Eanes de Zurara explora os discursos em primeira pessoa do fr. João Xira e do conde D. Pedro de Meneses a fim de convencer melhor o leitor e certificá-lo de que sua história era verídica. Os discursos dessas duas figuras foram reproduzidos - desse modo - para evidenciar palavras, apregoadas em torno da conquista e da administração de Ceuta, que pudessem transmitir aos homens do presente e das gerações futuras certas práticas típicas de um cavaleiro virtuoso.

As prédicas desses dois personagens das crônicas de Gomes Eanes de Zurara ajudaram a legar ricas impressões dos cavaleiros do tempo da conquista da praça de Ceuta a respeito do papel da fé cristã para a proteção dos portugueses diante dos inimigos mouros. Obras como as crônicas de Zurara abrem o caminho para explorar, tanto os pilares morais que fomentaram a incursão militar no corte da África, quanto a importância da figura de um confessor, o fr. João Xira, para acalmar os ânimos e incentivar a ação bélica dos cavaleiros enviados para essa região. 


\section{REFERÊNCIAS}

CALAFATE, P (org.). História do pensamento filosófico português. Idade Média. Lisboa: Caminho, 1999. v. 1.

CARVALHO, J. d. Sobre a autenticidade dos sermões de Fr. João Xira. (s.d.).

Disponível em: http://www.joaquimdecarvalho.org/. Acesso em: 10 abr. 2016.

CARVALHO, J. d. Sobre a erudição de Gomes Eanes de Zurara: notas em torno de alguns plágios deste cronista. Biblos, 25, 1949. Disponível em:

http://www.joaquimdecarvalho.org/. Acesso em: 10 abr. 2016.

CONTAMINE, P. War in the Middle Ages. Oxford: Blackwell, 2002.

DUARTE, D. Leal conselheiro. Ed. M. H. Castro. Lisboa: Imprensa Nacional - Casa da Moeda, 1998.

FRANÇA, S. S. Os reinos dos cronistas medievais (século XV). São Paulo:

Annablume; Brasília: Capes, 2006.

FREIRE, N.; GODINHO, H. (ed.). Horto do esposo. Lisboa: Edições Colibri, 2007.

GUENÉE, B. Histoire et culture historique dans l'Occident médiéval. Paris:

Editions Aubier Montaigne, 1980.

LA REAL ACADEMIA DE LA HISTORIA. Las siete partidas del rey don Alfonso el Sabio. Madrid: En la Imprenta Real, 1807. v. 2.

MACHADO, J. B. Dicionário dos primeiros livros impressos em língua portuguesa. Braga: Edições Vercial, 2015. v. 1.

MALEVAL, M. D. Caravelas e cavaleiros: das tomadas de Ceuta e Guiné. Limites: Anais. III Congresso da ABRALIC, Niterói-RJ, p. 257-264, 1992.

MARQUES, J. A pregação em Portugal na Idade Média. Alguns aspectos. Via Spiritus: revista de história da espiritualidade e do sentimento religioso, v. 9, p. 317-347, 2002.

MONGELLI, L. M. A literatura doutrinária na corte de Avis. São Paulo: Martins Fontes, 2001.

MORENO, H. B. O princípio da época moderna. In: TENGARRINHA, J. História de Portugal. Bauru, SP; São Paulo; Portugal, PO: EDUSC; UNESP; Instituto Camões, 2000. p. 47-56.

PEDRO, D. Livro da Virtuosa Benfeitoria. In: ALMEIDA, M. L. Obras dos pPríncipes de Avis. Porto: Lello \& Irmão, 1981. p. 525-763.

PINA, R. D. Chronica do senhor rey D. Duarte. In: ALMEIDA, M. L. Crónicas de Rui de Pina. Porto: Lello \& Irmão, 1977. p. 477-574. 
PIROSKA, N. Le don des larmes au Moyen Âge. Paris: Albin Michel, 2000.

PORTUGAL. Instituto da Biblioteca Nacional e do livro. No quinto centenário da Vita Christi. Os primeiros impressores alemães em Portugal. Coord. J. J. A. Dias. Lisboa: I.B.N.L., 1995.

SAXÓNIA, L. Vita Christi. Ed. J. B. Machado. Braga: Edições Vercial, 2013. v. 2.

SERRÃO, J. V. A historiografia portuguesa. Doutrina e Crítica. Séculos XII-XVI. Lisboa: Verbo, 1972. v. 1.

VENTURA, M. G. O messias de Lisboa: um estudo de mitologia política, 1383-1415. Lisboa: Edições Cosmos, 1992.

ZURARA, G. E. Crónica da Tomada de Ceuta. Ed. F. M. Pereira. Coimbra: Academia das Sciencias de Lisboa, 1915.

ZURARA, G. E. Crónica de Duarte de Meneses. Ed. L. King. Lisboa: Universidade Nova de Lisboa, 1978.

ZURARA, G. E. Crónica do conde D. Pedro de Meneses. Ed. M. T. Brocardo. Lisboa: Fundação Calouste Gulbenkian, 1997. 